\title{
Binding Properties of Mechanically Activated Nepheline Containing Mining Waste
}

\author{
Basya I. Gurevich, Elena V. Kalinkina and Alexander M. Kalinkin * \\ Tananaev Institute of Chemistry, Subdivision of the Federal Research Centre "Kola Science Centre of the Russian \\ Academy of Sciences", Akademgorodok 26a, Apatity 184209, Murmansk Region, Russia; \\ gurevich1931@yandex.ru (B.I.G.); kalinkina@chemy.kolasc.net.ru (E.V.K.) \\ * Correspondence: kalinkin@chemy.kolasc.net.ru; Tel.: +7-81555-79523
}

Received: 29 November 2019; Accepted: 1 January 2020; Published: 3 January 2020

\begin{abstract}
The development of apatite and rare-metal deposits of the Khibiny and Lovozero- - the world's largest ultrabasic massifs located in the Kola Alkaline Province-is accompanied by accumulation of huge amounts of sandy tailings dumps, about half consisting of nepheline. These tailings, on the one hand, pose a real threat of environmental pollution. On the other hand, they are "technogenic deposits" that contain reserves of valuable components $\left(\mathrm{Na}_{2} \mathrm{O}, \mathrm{K}_{2} \mathrm{O}, \mathrm{Al}_{2} \mathrm{O}_{3}\right.$, etc.). In this paper, methods of processing of the nepheline-containing mining waste using mechanical activation to produce binding materials-geopolymers and blended cements-are observed. The advantages of combining the nepheline containing tailings dumps with other mining wastes accumulated in the region, such as $\mathrm{Cu}-\mathrm{Ni}$ slag, are presented.
\end{abstract}

Keywords: mining waste; ore dressing tailings; nepheline; binding properties; mechanical activation

\section{Introduction}

The world's largest alkaline massifs-Khibiny and Lovozero-are located in Kola Peninsula (Murmansk Region, northwest of Russia). Over the past few decades, the development of apatite and rare-metal deposits of these massifs has accumulated a huge amount of mining waste. Among them, the largest ones are flotation tailings dumps of apatite-nepheline dressing plants of Joint-stock company "Apatit". The technological process of the production of apatite concentrate in apatite-nepheline dressing plants is accompanied by the accumulation of huge masses of fine sandy waste, about half consisting of nepheline. In the apatite-nepheline dressing plant ANDP-2 tailing dumps alone (Figure 1), which area is about $10 \mathrm{~km}^{2}$, by various estimations 550-630 million tons of nepheline containing tailings (NT) are accumulated. The total amount of such waste in the area of Kirovsk and Apatity (Murmansk Region, Russia) ranges between 800-900 million tons [1,2].

The nepheline containing tailings of the apatite-nepheline dressing plant ANDP-2 are a fine gray sand with a significant content of dusty fractions. The granulometric composition of these tailings sampled in 2005 is presented in Table 1 . The mineral composition of the nepheline containing tailings of apatite-nepheline dressing plant ANDP-2, wt. \%: nepheline 50-55, feldspars 2.5-4, secondary minerals with respect to nepheline $0.5-2$, aegirine $23-27$, titanomagnetite $4-5$, apatite $2-3.5$, titanite $4-5$ [3]. Table 2 presents the chemical composition of the nepheline containing tailings.

There are several technological schemes for obtaining nepheline concentrate (NC) from the nepheline containing tailings. The chemical composition of the nepheline concentrate is given in Table 2. The mineral composition of the nepheline concentrate, wt. \%: nepheline 70-85, feldspars 8-16, secondary minerals with respect to nepheline $1.5-5$, aegirine $23-27$, titanomagnetite $0.4-0.6$, apatite $0.2-0.8$, titanite $0.5-1.0$ [3]. The nepheline concentrate is processed in limited quantities into alumina, soda, potash, and Portland cement. The major part of nepheline is stored in the tailings. The proportion 
of nepheline produced in the form of the nepheline concentrate does not exceed $10 \%$ of its content in the mined apatite-nepheline ore [4].

The nepheline containing tailings, on the one hand, pose a real threat to the environment (mainly as a source of air pollution due to dusting). On the other hand, the nepheline containing tailings are a man-made deposit that contains reserves of valuable components $\left(\mathrm{Na}_{2} \mathrm{O}, \mathrm{K}_{2} \mathrm{O}, \mathrm{Al}_{2} \mathrm{O}_{3}\right.$, etc). The need for nepheline as a source of alumina, soda and potash is very limited. Therefore, it is relevant to search for alternative ways of disposing of the nepheline containing mining waste. The use of nepheline in the production of new binders can be very much in demand.

Table 1. Granulometric composition of the flotation tailings of apatite-nepheline dressing plant ANDP-2 [1].

\begin{tabular}{cccccc}
\hline Size of Fraction (mm) & $>0.224$ & $0.16-0.224$ & $0.09-0.16$ & $0.071-0.09$ & $<0.071$ \\
\hline Content of Fraction (wt. \%) & 20.15 & 12.9 & 18.6 & 14.9 & 33.45 \\
\hline
\end{tabular}

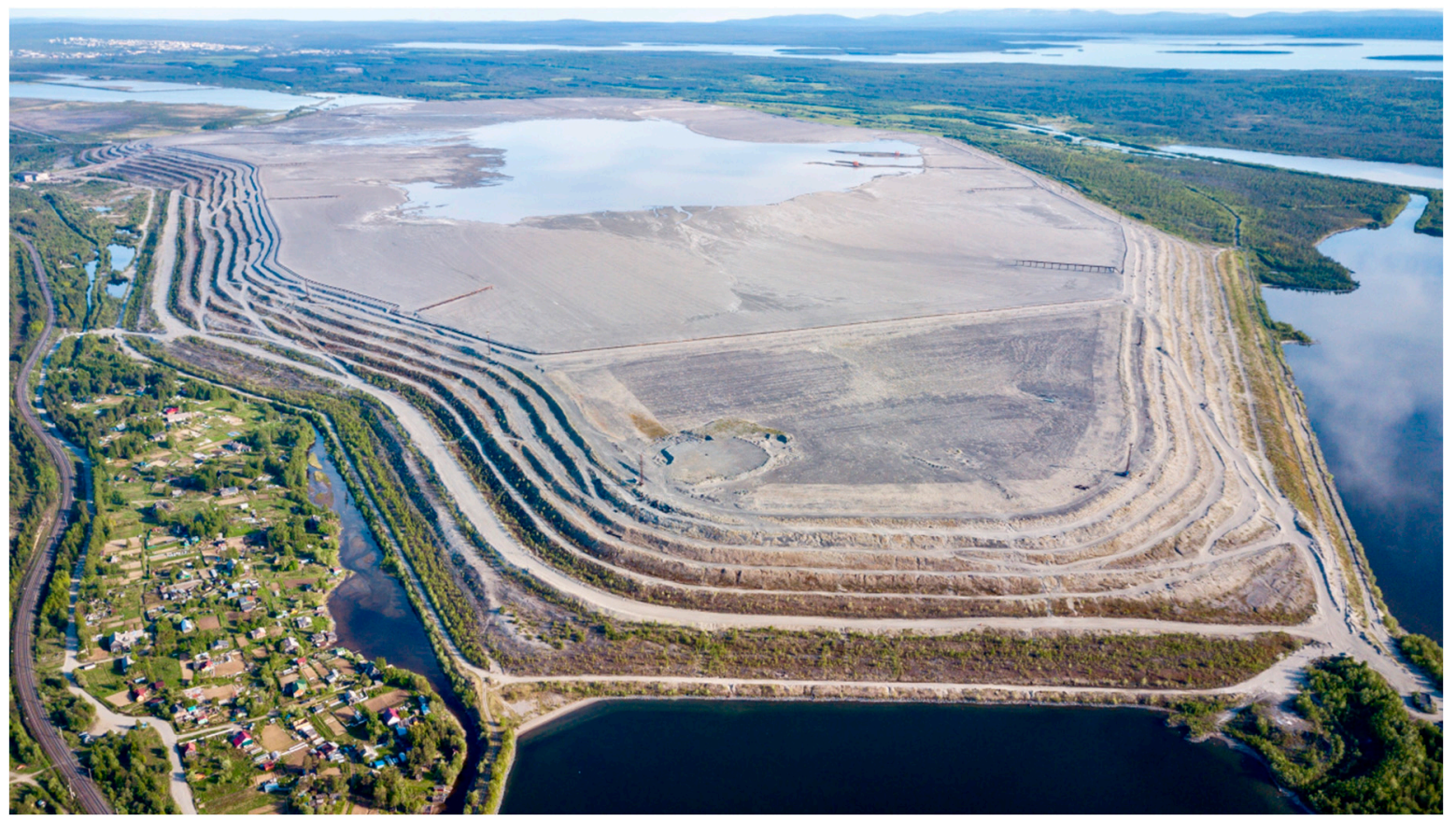

Figure 1. The flotation tailings dumps of apatite-nepheline dressing plant ANDP-2 of Joint-stock company "Apatit". Reproduced with permission from V.V. Petkevich.

Table 2. Chemical composition of the flotation tailings of apatite-nepheline dressing plant ANDP-2, nepheline concentrate, and $\mathrm{Cu}-\mathrm{Ni}$ slag (wt. \%).

\begin{tabular}{cccccccccccc}
\hline $\begin{array}{c}\text { Mineral } \\
\text { Component }\end{array}$ & $\mathrm{SiO}_{2}$ & $\mathrm{Al}_{2} \mathbf{O}_{3}$ & $\mathbf{F e O}$ & $\mathrm{Fe}_{2} \mathbf{O}_{3}$ & $\mathbf{C a O}$ & $\mathbf{M g O}$ & $\mathbf{N a}_{2} \mathbf{O}$ & $\mathbf{K}_{\mathbf{2}} \mathbf{O}$ & $\mathrm{TiO}_{2}$ & $\mathbf{P}_{\mathbf{2}} \mathbf{O}_{5}$ & $\mathbf{L O I}$ \\
\hline $\begin{array}{c}\text { Flotation } \\
\text { tailings }\end{array}$ & 37.90 & 19.19 & - & 8.82 & 5.52 & 1.29 & 9.65 & 5.77 & 2.63 & 1.48 & - \\
$\begin{array}{c}\text { Nepheline } \\
\text { concentrate }\end{array}$ & 43.37 & 29.48 & - & 2.90 & 0.84 & 0.27 & 12.80 & 9.01 & 0.27 & 0.03 & 1.13 \\
\begin{tabular}{c} 
Cu-Ni slag \\
\hline
\end{tabular} & 40.88 & 6.90 & 35.40 & - & 2.65 & 10.71 & 1.18 & 0.92 & - & - & - \\
\hline
\end{tabular}

Nepheline is a rock-forming mineral, a framework aluminosilicate of potassium and sodium with idealized composition $\mathrm{Na}_{3} \mathrm{KAl}_{4} \mathrm{Si}_{4} \mathrm{O}_{16}$. The crystal structure of nepheline (Figure 2) belongs to the type of trimidite where half of the silicon atoms are replaced by aluminum. As a result of such a replacement, the alumina-silicon-oxygen group acquires negative charge, which is compensated by 
sodium and potassium cations. The mineral framework is formed by distorted 6-membered rings of $\mathrm{SiO}_{4}$ and $\mathrm{AlO}_{4}$ tetrahedra connected to each other by their vertices, and alkali metal ions are in the cavities of the structure. There are two types of 6-membered rings of tetrahedra: one quarter of the rings is almost regular, and three quarters of the rings are highly distorted. The general pattern of Al-Si ordering in nepheline is shown in Figure 2 by $\mathrm{T}(1), \mathrm{T}(2), \mathrm{T}(3)$, and $\mathrm{T}(4)$ tetrahedra.

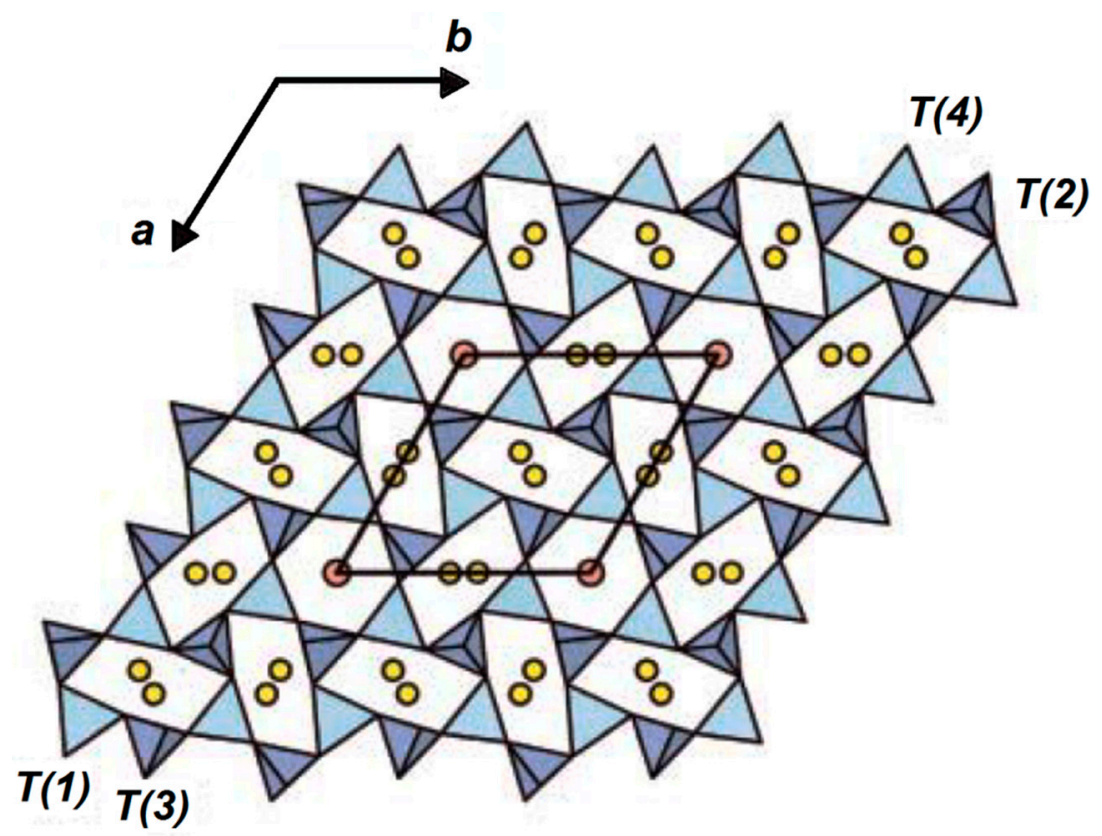

Figure 2. The crystal structure of the nepheline projected onto (001). The $\mathrm{T}(2)$ and $\mathrm{T}(3)$ tetrahedra $(\mathrm{Si}>\mathrm{Al})$ are navy blue, the $\mathrm{T}(1)$ and $\mathrm{T}(4)$ tetrahedra $(\mathrm{Al}>\mathrm{Si})$ are greenish blue, the $\mathrm{K}$ sites are shown as orange spheres, and the Na sites, as yellow spheres. Reproduced with permission from [5], published by The Canadian Mineralogist, 2003.

In the middle of the last century, Glukhovsky and co-workers showed that highly basic minerals, such as nepheline, can be used to produce cements, if they were previously transferred from a stable crystalline state to a more active vitreous form [6]. Finely ground glasses of an alkaline aluminosilicate with a composition close to natural nepheline exhibited hydraulic activity not only during heat and moisture treatment, but also at ambient curing conditions. According to the authors of [6], nepheline cement is a fine ground glass of nepheline composition, obtained by melting of natural nepheline. The nepheline cement is a hydraulic binder. It gained strength and water resistance due to the formation of alkaline hydroaluminosilicates similar in composition and structure to natural minerals such as zeolites. The hydraulic properties of the nepheline cement were enhanced by activating it with dilute alkali solutions. The degree of hydration of the nepheline cement increased by autoclaving. A characteristic feature of the nepheline cement was that, when heated, its hydration products first transformed into anhydrous amorphous phases without a significant change in the volume of the solid phase and loss of strength. With a further increase in temperature, these phases recrystallized into nepheline. Because of this, the nepheline cement was recommended for preparation of heat-resistant concrete [6].

In addition to vitrification, another effective tool to increase the reactivity of solids is mechanical activation (MA) [7-10]. The term mechanical activation is applied here to the structural-chemical changes on the surface and in the bulk of solid caused by milling. In this review, binding properties of geopolymers and blended cements prepared using the mechanically activated nepheline containing tailings and nepheline concentrate are presented. 


\section{Geopolymers Prepared Using the Nepheline Concentrate and the Nepheline Containing Tailings Dumps}

Geopolymers (inorganic polymers) are a subclass of alkali activated binders. Geopolymers are prepared by mixing of natural or technogenic low-calcium aluminosilicates with alkaline agents (sodium or potassium hydroxide solutions, liquid glass). They harden at ambient temperature and are used as environmentally friendly building materials alternative to Portland cement [11-16]. The advantages of geopolymer binders for replacing traditional Portland cement in particular are supported by the fact that in various industries there are many by-products that are suitable for use as raw materials for geopolymers [17-19]. In recent years, there has been an increasing number of studies on the use of mining waste in the preparation of geopolymer materials both as a component of an alkali-activated binder and as an aggregate [20-34]. Geopolymer materials display special physical-mechanical and technical properties: high durability and strength, particularly bending strength; resistance to chemical aggressive environments, and high temperatures. They can be used as a matrix for immobilization of toxic waste, as sorbents for waste water treatment and for other applications [35-39]. All this has stimulated in recent years the rapid growth of research and development on the geopolymers. It should be noted that, for improving the mechanical properties of the geopolymers, the efficiency of mechanical activation is well established [34,40-46].

Nepheline contains all the components necessary for geopolymer synthesis: aluminum, silicon, and alkali metals. However, crystalline nepheline itself exhibited a very weak hydraulic activity. The compressive strength of samples based on the nepheline concentrate milled to specific surface area ca. $1000 \mathrm{~m}^{2} \cdot \mathrm{kg}^{-1}$ and cured under relative humidity of $95 \pm 5 \%$ at temperature of $20-22{ }^{\circ} \mathrm{C}$ for 180 days was $0.9 \mathrm{MPa}$ only [47]. This necessitated the increase of reactivity of nepheline-containing raw materials. As indicated above, an increase in the hydraulic activity of nepheline can be achieved by its transformation to a metastable vitreous form or by its mechanical activation.

Another valuable technogenic mineral raw material which is of interest for the production of binders is granulated magnesia-ferrous slag of copper-nickel smelter plants in the Murmansk region, Russia. It is well known that alkali activated binders based on blast furnace slag have been extensively investigated since the 1960s when Glukhovsky and coworkers developed their synthesis and applied it in the construction industry $[6,48,49]$. The granulated $\mathrm{Cu}-\mathrm{Ni}$ magnesia-ferrous slag is different in chemical composition from blast furnace slag. Magnesium, silicon, and iron oxides prevail in its composition and the content of $\mathrm{CaO}$ is only about $2-3 \mathrm{wt}$. \%. Because of this, the hydraulic activity of the $\mathrm{Cu}-\mathrm{Ni}$ slag is lower relative to that of blast furnace slag. However, Gurevich and Zosin [50] as long ago as in 1965 developed the slag-alkali binder based on the granulated $\mathrm{Cu}-\mathrm{Ni}$ slag. Later, the lime-slag binder and the Portland cement-slag binder were developed based on the $\mathrm{Cu}-\mathrm{Ni}$ slag [51]. Hydration activity of the $\mathrm{Cu}-\mathrm{Ni}$ slag can be significantly increased by $\mathrm{MA}$ in a $\mathrm{CO}_{2}$ atmosphere. Compressive strengths of the alkali activated binders based on the slag mechanically activated in air after curing at room temperature for $1,7,28,150$, and 360 days were $51,75,81,83$, and $90 \mathrm{MPa}$, respectively. When using mechanical activation in $\mathrm{CO}_{2}$, the corresponding values were $54,77,94,106$, and $119 \mathrm{MPa}$, respectively [52].

In this section, the binding properties of the following nepheline containing compositions prepared using mechanical activation of the solid components in air and in $\mathrm{CO}_{2}$ are reviewed:

1) NC-Cu-Ni slag-water;

2) NC-Cu-Ni slag-liquid glass;

3) NT-alkali agent (liquid glass or $\mathrm{NaOH}$ solution);

4) NT-Cu-Ni slag-liquid glass.

\subsection{The Nepheline Concentrate-Cu-Ni Slag-Water Binder}

The binding properties of the nepheline concentrate- $\mathrm{Cu}-\mathrm{Ni}$ slag-water composition were studied in [47]. In this mixture, the nepheline concentrate substituted $20,30,50$, and $80 \%$ of the slag. The $\mathrm{Cu}-\mathrm{Ni}$ 
granulated (water-cooled) slag was obtained from Pechenganickel smelter plant (Murmansk Region, Russia). The slag mainly consisted of magnesia-ferriferous glass (95-98 wt. \%) with minor amount of the crystalline phases of olivine (1-5 wt. \%) and ore minerals (1-3 wt. \%). Chemical composition of the slag is given in Table 2.

Mechanical activation of the nepheline concentrate-Cu-Ni slag mixture was carried out in an AGO-2 laboratory centrifugal-planetary mill [8] at a centrifugal factor of $40 \mathrm{~g}$ for $270 \mathrm{~s}$ in air and in $\mathrm{CO}_{2}$ atmosphere $\left(\mathrm{P}=10^{5} \mathrm{~Pa}\right)$. Steel balls $8 \mathrm{~mm}$ in diameter were used as milling bodies. The ratio between the masses of the balls and a slag sample was 6 . The specific surface area was measured by Blaine method.

The mechanically activated nepheline concentrate- $\mathrm{Cu}-\mathrm{Ni}$ slag blend was mixed with water to prepare cubic specimens. The specimens were cured under relative humidity of $95 \pm 5 \%$ at temperature of $20-22^{\circ} \mathrm{C}$ until tested in compression [47]. Compressive strength of the nepheline concentrate- $\mathrm{Cu}-\mathrm{Ni}$ slag-water binder is presented in Figure 3 and Table 3. The compressive strength of the binder based on the $100 \%$ nepheline concentrate mechanically activated in $\mathrm{CO}_{2}$ (Figure 3) and in air (Table 3) in the age of 360 days was 1.5 MPa only. The corresponding values of the binders based on the $100 \%$ slag mechanically activated in air and in $\mathrm{CO}_{2}$ were 3.1 and $23.8 \mathrm{MPa}$, respectively. As was shown in [52,53], mechanical activation of the slag in carbon dioxide atmosphere was accompanied by sorption of $\mathrm{CO}_{2}$ in the form of distorted carbonate groups by the outer layers of the slag particles. This resulted in higher reactivity and faster hydration of the slag carbonized by mechanical activation in $\mathrm{CO}_{2}$ in comparison to those of the slag mechanically activated in air.

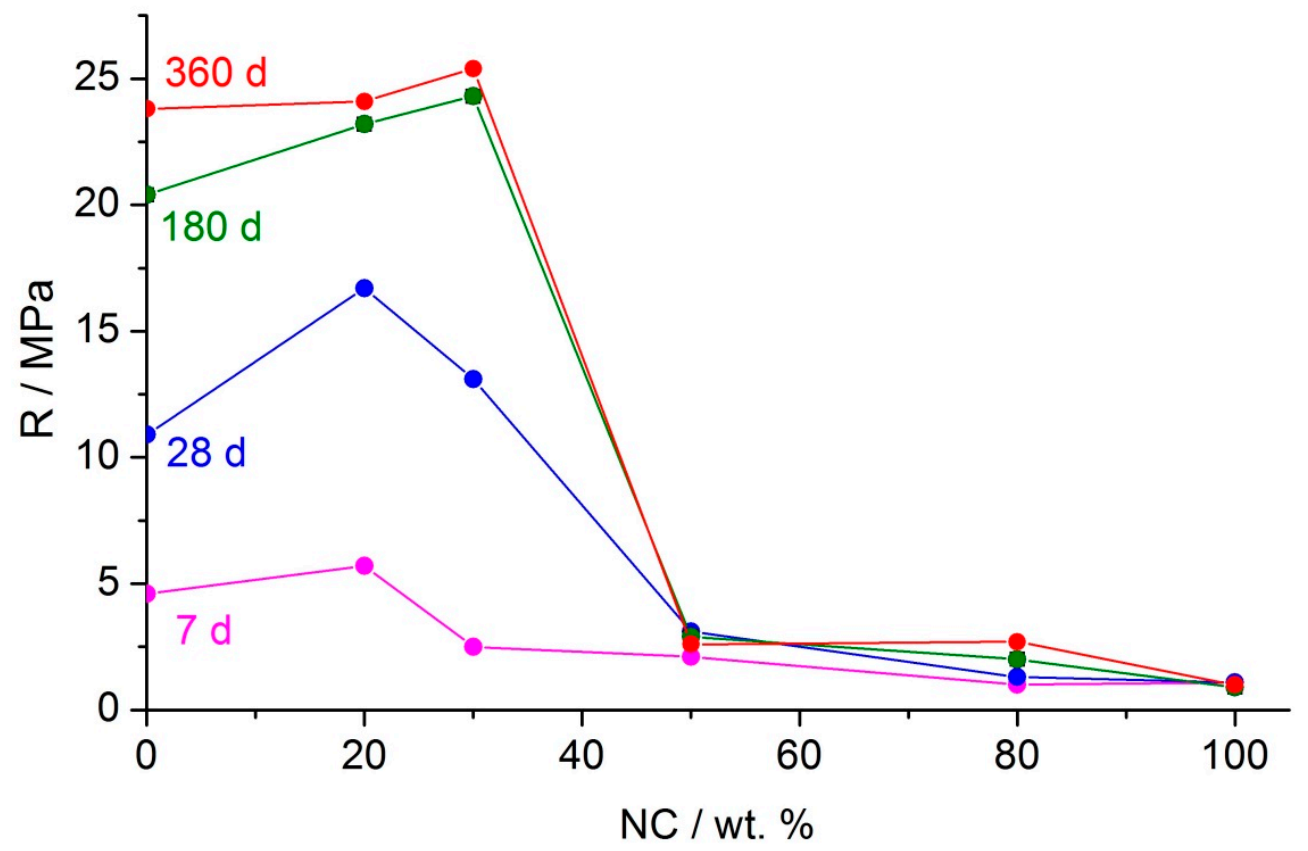

Figure 3. Compressive strength (R) of the NC-Cu-Ni slag-water binder at 7, 28, 180, and 360 days of age as a function of percentage mass of the NC in the mixture $\mathrm{NC}-\mathrm{Cu}-\mathrm{Ni}$ slag mechanically activated in $\mathrm{CO}_{2}$. Reproduced with permission from [47], published by Prospective Materials, 2015.

For the nepheline concentrate-Cu-Ni slag-water binder prepared using mechanical activation in air, the compressive strength for all curing periods was in the range of $1-3 \mathrm{MPa}$ (Table 3). When $\mathrm{CO}_{2}$ was used as an atmosphere of mechanical activation, the strength of the binders in which the slag fraction was more than $70 \mathrm{wt}$. \% increased by an order of magnitude, exceeding $20 \mathrm{MPa}$ after curing for 180-360 days (Figure 3). Thus, the addition of 20-30\% nepheline concentrate to the slag contributed to an increase in the strength of the nepheline concentrate-Cu-Ni slag binder compared to that of the binder based on the slag without the nepheline concentrate (Figure 3). This means that nepheline was not an inert "diluent" in the slag-nepheline blend, but an active component. 
Table 3. The compressive strength (R) of the NC-Cu-Ni slag-water binder. MA was carried out in air for $270 \mathrm{~s}$ (w/s: water to solid ratio; $\mathrm{S}_{\mathrm{sp}}$ : the specific surface area of the $\mathrm{NC}-\mathrm{Cu}-\mathrm{Ni}$ slag mixture).

\begin{tabular}{|c|c|c|c|c|c|c|c|}
\hline \multicolumn{2}{|c|}{ Composition, wt. $\%$} & \multirow{2}{*}{$S_{s p}, m^{2} \cdot k^{-1}$} & \multirow{2}{*}{$\mathbf{w} / \mathbf{s}$} & \multicolumn{4}{|c|}{$\mathrm{R}, \mathrm{MPa}$} \\
\hline Nepheline Concentrate & Cu-Ni Slag & & & $7 \mathrm{~d}$ & $28 \mathrm{~d}$ & $180 \mathrm{~d}$ & $360 \mathrm{~d}$ \\
\hline 100 & - & 1062 & 0.31 & 1.1 & 1.1 & 0.9 & 1.5 \\
\hline- & 100 & 470 & 0.23 & 0.6 & 1.0 & 2.0 & 3.1 \\
\hline 20 & 80 & 548 & 0.26 & 0.2 & 0.7 & 0.9 & 0.83 \\
\hline 30 & 70 & 604 & 0.26 & 0.2 & 0.7 & 1.5 & 0.97 \\
\hline 50 & 50 & 714 & 0.26 & 1.0 & 2.0 & 1.8 & 1.9 \\
\hline 80 & 20 & 881 & 0.26 & 0.3 & 1.3 & 2.4 & 0.57 \\
\hline
\end{tabular}

To assess the increase in the reactivity of the nepheline concentrate due to mechanical activation, the nepheline concentrate was leached with water [47]. Leaching degree was calculated as the amount of oxides leached to the solution from the mechanically activated nepheline concentrate to its amount contained in the nepheline concentrate. From Table 4, it is seen that the leaching degree of sodium and potassium oxides did not exceed 5-6\%. The atmosphere of mechanical activation (air or $\mathrm{CO}_{2}$ ) did not significantly affect the degree of leaching. The leaching degree of silicon and aluminum was not more than $1 \%$ and the $\mathrm{pH}$ of the solution was $10-11$. Hence, mechanical activation of the nepheline concentrate-Cu-Ni slag mixture and the subsequent addition of water led to leaching of small amount of $\mathrm{Na}, \mathrm{K}, \mathrm{Si}$, and $\mathrm{Al}$ into the aqueous phase, and to the increase of the $\mathrm{pH}$ to some extent. However, as shown in Figure 3, it seems likely that this was sufficient to increase strength by 10-20\% (depending on the curing period), compared with that of the binder based on the slag without the nepheline concentrate. A characteristic feature of this "alkali activated" binder was that the alkaline agent was not added in the form of externally prepared alkali solution but was formed in situ upon leaching of nepheline when water was added to the mechanically activated mixture of the nepheline concentrate and the slag.

Table 4. The water leaching degree of $\mathrm{Na}_{2} \mathrm{O}, \mathrm{K}_{2} \mathrm{O}, \mathrm{Al}_{2} \mathrm{O}_{3}$, and $\mathrm{SiO}_{2}$ from the nepheline concentrate mechanically activated for $270 \mathrm{~s}$ (w/s: water to solid ratio).

\begin{tabular}{|c|c|c|c|c|c|c|c|c|}
\hline \multirow{2}{*}{$\mathrm{w} / \mathrm{s}$} & \multirow{2}{*}{$\mathrm{pH}$} & \multirow{2}{*}{$\begin{array}{c}\text { MA } \\
\text { Atmosphere }\end{array}$} & \multirow{2}{*}{$\begin{array}{l}\text { Leaching } \\
\text { Time, h }\end{array}$} & \multirow{2}{*}{$\begin{array}{c}\text { Leaching } \\
\text { Temperature, }{ }^{\circ} \mathrm{C}\end{array}$} & \multicolumn{4}{|c|}{ Leaching Degree, \% } \\
\hline & & & & & $\mathrm{Na}_{2} \mathrm{O}$ & $\mathrm{K}_{2} \mathrm{O}$ & $\mathrm{Al}_{2} \mathrm{O}_{3}$ & $\mathrm{SiO}_{2}$ \\
\hline 1:10 & 10.71 & \multirow{3}{*}{ Air } & \multirow{3}{*}{6} & \multirow{3}{*}{20} & 2.28 & 0.67 & 0.17 & 0.0069 \\
\hline $1: 20$ & 10.78 & & & & 2.99 & 0.82 & 0.28 & 0.012 \\
\hline 1:50 & 10.62 & & & & 3.74 & 1.22 & 0.77 & 0.007 \\
\hline 1:10 & 10.01 & \multirow{3}{*}{$\mathrm{CO}_{2}$} & \multirow{3}{*}{6} & \multirow{3}{*}{20} & 2.52 & 1.11 & 0.34 & 0.060 \\
\hline $1: 20$ & 10.11 & & & & 3.46 & 1.49 & 0.68 & 0.17 \\
\hline 1:50 & 10.25 & & & & 4.33 & 1.56 & 0.77 & 0.099 \\
\hline 1:10 & 11.3 & \multirow{3}{*}{ Air } & \multirow{3}{*}{1} & \multirow{3}{*}{75} & 2.76 & 0.92 & 0.34 & 0.13 \\
\hline $1: 20$ & 11.05 & & & & 4.10 & 1.27 & 0.70 & 0.23 \\
\hline 1:50 & 10.7 & & & & 5.32 & 1.98 & 1.27 & 0.67 \\
\hline $1: 3$ & 10.93 & \multirow{3}{*}{ Air } & \multirow{3}{*}{3} & \multirow{3}{*}{20} & 1.56 & 0.537 & 0.119 & 0.006 \\
\hline $1: 4$ & 10.91 & & & & 1.86 & 0.604 & 0.148 & 0.012 \\
\hline $1: 5$ & 10.83 & & & & 2.05 & 0.683 & 0.185 & 0.017 \\
\hline
\end{tabular}

\subsection{The Nepheline Concentrate-Cu-Ni Slag-Liquid Glass Binder}

Figure 4 presents the compressive strength of the geopolymer binder prepared using the mechanically activated nepheline concentrate and liquid glass as a function of the measured surface area of the nepheline concentrate and time of mechanical activation in air. Curing was carried out under relative humidity of $95 \pm 5 \%$ at temperature of $20-22{ }^{\circ} \mathrm{C}$ [3]. As MA time increased, so did the specific surface area of the nepheline concentrate (Figure 4) and the half-widths of the X-ray diffraction 
peaks of nepheline in XRD patterns of the nepheline concentrate (not shown). Thus, mechanical activation led to the accumulation of the excess energy by the nepheline concentrate and increasing its reactivity. As a result, the compressive strength of the binder continuously increased with increase in mechanical activation time for all curing periods. At $360 \mathrm{~d}$ of age, the compressive strength of the binder based on the nepheline concentrate mechanically activated for $270 \mathrm{~s}$ was $4.9 \mathrm{MPa}$. Hence, the compressive strength increased by more than 3-fold relative to that of the binder based on the nepheline concentrate mechanically activated for $30 \mathrm{~s}(1.5 \mathrm{MPa})$.

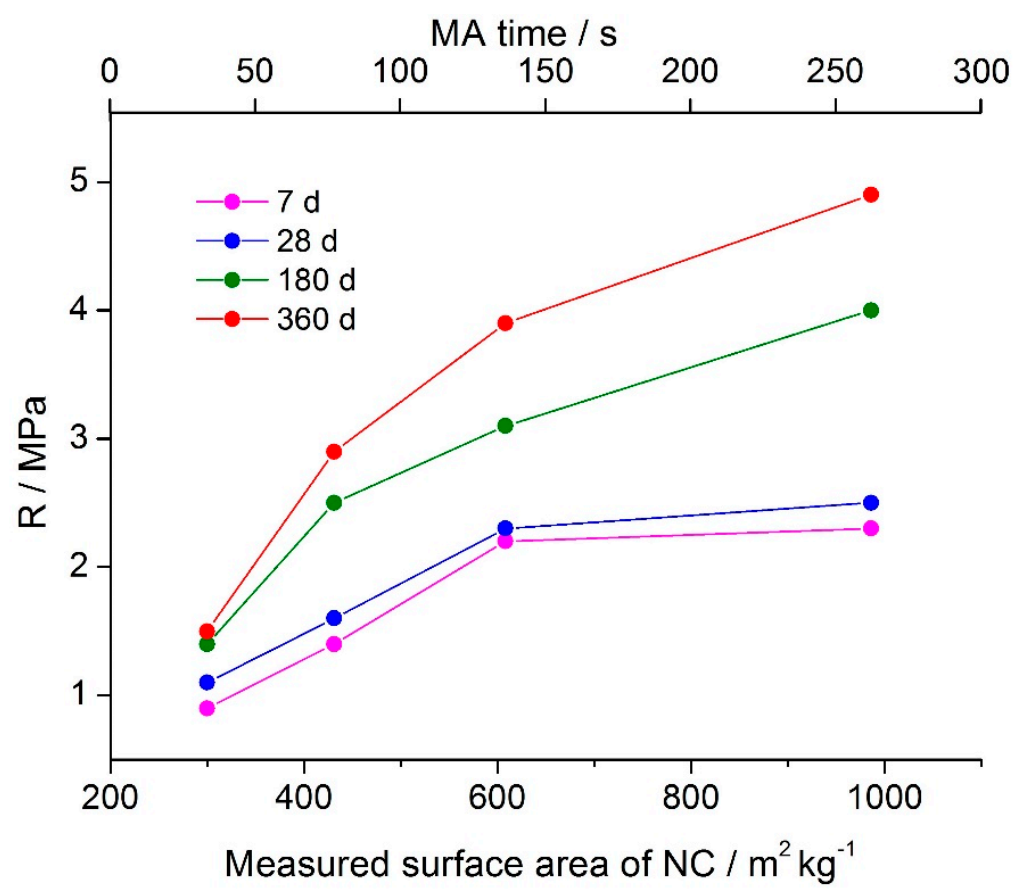

Figure 4. The compressive strength (R) of the geopolymer binder based on the NC at 7, 28, 180, and $360 \mathrm{~d}$ of age as a function of the measured surface area of the NC and time of MA in air. Activator solution: liquid glass containing $3 \mathrm{wt}$. $\% \mathrm{Na}_{2} \mathrm{O}$ (relative to weight of the $\mathrm{NC}$ ) with silica modulus of 1.50 .

Addition of the $\mathrm{Cu}-\mathrm{Ni}$ slag to the nepheline concentrate, as in case of the nepheline concentrate-Cu-Ni slag-water binder (Figure 3), resulted in increase of the compressive strength relative to the binder based on the nepheline concentrate without the slag, regardless of the MA atmosphere (air or $\mathrm{CO}_{2}$ ) [3] (Table 5). In this binder, the slag substituted from 1 to $30 \mathrm{wt}$. \% of the nepheline concentrate. For the binder based on the $100 \%$ nepheline concentrate mechanically activated in $\mathrm{CO}_{2}$, the compressive strength at $360 \mathrm{~d}$ of age was $4.9 \mathrm{MPa}$, while, for the binder with a ratio of nepheline concentrate: slag equaled to 7:3 the corresponding value was $21.9 \mathrm{MPa}$, i.e., 4.5 times larger. The advantage of carbon dioxide as an atmosphere of mechanical activation was clearly visible for the long-term curing (180 and $360 \mathrm{~d}$ ) while at age of $28 \mathrm{~d}$ and less it was not the case (Table 5).

The properties of the nepheline concentrate-Cu-Ni slag-liquid glass binder were studied also using curing in water at $20-22{ }^{\circ} \mathrm{C}$. The water resistance coefficient designated as $\mathrm{K}^{28}$ was determined by the ratio of the compressive strength of the binder cured in water at temperature of $20-22{ }^{\circ} \mathrm{C}$ for 28 days to the corresponding value of the binder cured in air under relative humidity of $95 \pm 5 \%$ at the same temperature for the same time. It was found that, for the binder based on the mechanically activated nepheline concentrate without the slag, the $\mathrm{K}^{28}$ value was in the range of $0.48-0.60$ only. Addition of the slag to nepheline concentrate in amount of $1-5 \mathrm{wt}$. \% resulted in increase of $\mathrm{K}^{28}$ up to $0.91[3]$. 
Table 5. The compressive strength (R) of the NC-Cu-Ni slag-liquid glass binder. MA was carried out for 270 s. Liquid glass contained $2.68 \mathrm{wt}$. \% $\mathrm{Na}_{2} \mathrm{O}$ relative to weight of the ( $\mathrm{NC}+\mathrm{Cu}-\mathrm{Ni}$ slag) mixture; silica modulus of liquid glass was 1.59 . Curing was carried out under relative humidity of $95 \pm 5 \%$ at temperature of $20-22{ }^{\circ} \mathrm{C}\left(\mathrm{w} / \mathrm{s}\right.$ : water to solid ratio; $\mathrm{S}_{\mathrm{sp}}$ : the specific surface area of the $\mathrm{NC}-\mathrm{Cu}-\mathrm{Ni}$ slag mixture).

\begin{tabular}{|c|c|c|c|c|c|c|c|}
\hline \multicolumn{2}{|c|}{ Composition, wt. $\%$} & \multirow{2}{*}{$\mathrm{S}_{\mathrm{sp}}, \mathrm{m}^{2} \cdot \mathrm{kg}^{-1}$} & \multirow{2}{*}{ w/s } & \multicolumn{4}{|c|}{$\mathrm{R}, \mathrm{MPa}$} \\
\hline Nepheline Concentrate & Cu-Ni slag & & & $7 \mathrm{~d}$ & $28 \mathrm{~d}$ & $180 \mathrm{~d}$ & $360 d$ \\
\hline \multicolumn{8}{|l|}{$\mathrm{MA}$ in $\mathrm{CO}_{2}$} \\
\hline 100 & - & 986 & 0.22 & 2.3 & 2.5 & 4.9 & 4.9 \\
\hline 99 & 1 & 983 & 0.30 & 2.4 & 2.7 & 5.8 & 6.5 \\
\hline 97 & 3 & 975 & 0.28 & 3.3 & 3.5 & 7.2 & 7.0 \\
\hline 95 & 5 & 858 & 0.28 & 4.2 & 5.3 & 9.7 & 11.6 \\
\hline 90 & 10 & 959 & 0.27 & 5.7 & 9.2 & 14.0 & 17.2 \\
\hline 80 & 20 & - & 0.25 & 9.2 & 15.5 & 16.0 & 18.6 \\
\hline 70 & 30 & - & 0.24 & 13.2 & 18.5 & 21.1 & 21.9 \\
\hline \multicolumn{8}{|l|}{ MA in air } \\
\hline 99 & 1 & 1016 & 0.30 & 2.7 & 3.7 & 5.7 & 6.7 \\
\hline 97 & 3 & 1007 & 0.28 & 3.2 & 4.2 & 7.1 & 7.7 \\
\hline 95 & 5 & 1022 & 0.28 & 3.9 & 5.6 & 7.6 & 9.8 \\
\hline 90 & 10 & 996 & 0.27 & 5.7 & 7.4 & 9.4 & 11.5 \\
\hline
\end{tabular}

\subsection{The Nepheline Containing Tailings-Alkali Agent (Liquid Glass or NaOH Solution) Binder}

The nepheline content in the nepheline containing tailings was approximately 1.5 times lower than that in the nepheline concentrate (Table 2). The nepheline containing tailings and the nepheline concentrate also differed in apatite content and, accordingly, in $\mathrm{P}_{2} \mathrm{O}_{5}$ content. In the nepheline concentrate, the content of $\mathrm{P}_{2} \mathrm{O}_{5}$ was at the level of hundredths of a percent, while, in the nepheline containing tailings, this value was $1.48 \mathrm{wt}$. \%. To find the optimal combination of liquid glass modulus and its amount in a mixture with the mechanically activated nepheline containing tailings, the experiments were carried out according to the following scheme [3]. The amount of liquid glass in the binder varied from 2 to $10 \% \mathrm{Na}_{2} \mathrm{O}$ (with respect to the weight of the nepheline containing tailings). For each fixed value of $\mathrm{Na}_{2} \mathrm{O}$, specimens were prepared using liquid glass of various silica modulus (MS) from $\mathrm{MS}=0(\mathrm{NaOH}$ solution) to $\mathrm{MS}=2.77$. The prepared specimens were kept for $1 \mathrm{~d}$ in air at room temperature and then subjected to heat treatment in an oven in closed containers at $80^{\circ} \mathrm{C}$ for $6 \mathrm{~h}$, followed by curing in air at a relative humidity of $60-70 \%$ at $20-22^{\circ} \mathrm{C}$. According to the obtained results, the highest compressive strength was achieved for the formulations with $2-3 \mathrm{wt} . \% \mathrm{Na}_{2} \mathrm{O}$ using liquid glass with MS of 2.34 (Table 6). It is worth mentioning that the compressive strength of the binders prepared using liquid glass with MS of 2.34 and contained $2 \%$ and $3 \% \mathrm{Na}_{2} \mathrm{O}$ was at $180 \mathrm{~d}$ age 66.7 MPa and 45.8 $\mathrm{MPa}$, respectively. Sodium hydroxide solution was less effective as alkaline agent as compared to liquid glass.

Table 7 shows the effect of the silica modulus on the strength of binders based on the nepheline containing tailings under conditions of humid (relative humidity of 95-100\%) and relatively dry (relative humidity of $60-70 \%$ ) curing without the use of heat treatment [3]. Under both conditions of curing, with an increase in the MS, the strength of the samples increased. Under the relatively dry curing, this tendency was more pronounced. Therefore, of the two curing conditions, the relatively dry one was preferred. The strength of the binders prepared using liquid glass with silica modulus of 2.34 at $28 \mathrm{~d}$ of age reached $15.1 \mathrm{MPa}$ and $46.2 \mathrm{MPa}$ with the humid and dry curing, respectively. 
Table 6. The compressive strength (R) of the NT-alkaline agent binder prepared using heat treatment. MA of the NT was carried out in air for $270 \mathrm{~s}$. The percentage of $\mathrm{Na}_{2} \mathrm{O}$ corresponded to the sodium oxide in alkaline agent (liquid glass or $\mathrm{NaOH}$ solution) relative to weight of the NT. Curing conditions are described in the text (MS: silica modulus).

\begin{tabular}{|c|c|c|c|c|}
\hline \multirow{2}{*}{ MS } & \multicolumn{4}{|c|}{$\mathrm{R}, \mathrm{MPa}$} \\
\hline & $1 \mathrm{~d}$ & $7 \mathrm{~d}$ & $28 \mathrm{~d}$ & $180 \mathrm{~d}$ \\
\hline \multicolumn{5}{|l|}{$2 \% \mathrm{Na}_{2} \mathrm{O}$} \\
\hline 0 & 2.5 & 5.1 & 8.2 & 8.0 \\
\hline 1.22 & 3.1 & 6.3 & 10.2 & 9.9 \\
\hline 2.34 & 20.0 & 43.4 & 58.4 & 66.7 \\
\hline 2.77 & 11.5 & 13.0 & 13.9 & 2.6 \\
\hline \multicolumn{5}{|l|}{$3 \% \mathrm{Na}_{2} \mathrm{O}$} \\
\hline 0 & 2.8 & 5.4 & 15.9 & 16.3 \\
\hline 1.22 & 2.9 & 5.6 & 16.2 & 16.5 \\
\hline 2.34 & 12.1 & 37.8 & 41.5 & 45.8 \\
\hline 2.77 & 19.5 & 30.8 & 34.2 & 35.4 \\
\hline \multicolumn{5}{|l|}{$4 \% \mathrm{Na}_{2} \mathrm{O}$} \\
\hline 2.77 & 12.5 & 32.4 & 38.4 & 39.4 \\
\hline 2.34 & 18.2 & 27.2 & 34.3 & 32.6 \\
\hline \multicolumn{5}{|l|}{$5 \% \mathrm{Na}_{2} \mathrm{O}$} \\
\hline 0 & 1.9 & 3.6 & 4.7 & 6.3 \\
\hline 1.22 & 8.1 & 21.9 & 40.9 & 43.3 \\
\hline \multicolumn{5}{|l|}{$10 \% \mathrm{Na}_{2} \mathrm{O}$} \\
\hline 0 & 0.5 & 0.7 & 1.0 & 1.8 \\
\hline 1.22 & 0.5 & 0.5 & 1.6 & 1.9 \\
\hline
\end{tabular}

Table 7. The compressive strength (R) of the NT-alkaline agent binder. MA of the NT was carried out in air for $270 \mathrm{~s}$. The percentage of $\mathrm{Na}_{2} \mathrm{O}$ corresponded to the sodium oxide in alkaline agent (liquid glass or $\mathrm{NaOH}$ solution) relative to weight of the NT; silica modulus of liquid glass was 1.59 (MS: silica modulus).

\begin{tabular}{|c|c|c|c|}
\hline MS & $\mathrm{S}_{\mathrm{sp}}, \mathrm{m}^{2} \cdot \mathrm{kg}^{-1}$ & \multicolumn{2}{|c|}{$\mathrm{R}, \mathrm{MPa}$} \\
\hline \multicolumn{4}{|c|}{ curing in air at a relative humidity of $95-100 \%$ at $20-22{ }^{\circ} \mathrm{C}$} \\
\hline & & $7 \mathrm{~d}$ & $28 \mathrm{~d}$ \\
\hline 0 & 1250 & 0.5 & 0.8 \\
\hline 1.22 & 1250 & 7.8 & 8.6 \\
\hline 2.04 & 1250 & 8.1 & 8.6 \\
\hline 2.34 & 1250 & 14.9 & 15.1 \\
\hline \multicolumn{4}{|c|}{ curing in air at a relative humidity of $60-70 \%$ at $20-22{ }^{\circ} \mathrm{C}$} \\
\hline & & $7 \mathrm{~d}$ & $28 \mathrm{~d}$ \\
\hline 0 & 1246 & 2.3 & 3.4 \\
\hline 1.22 & 1246 & 14.1 & 15.4 \\
\hline 2.04 & 1246 & 9.2 & 10.3 \\
\hline 2.34 & 1246 & 24.3 & 46.2 \\
\hline
\end{tabular}

\subsection{The Nepheline Containing Tailings-Cu-Ni Slag-Liquid Glass Binder}

The compressive strength of the nepheline containing tailings-Cu-Ni slag-liquid glass binder is presented in Table 8. Considering the results obtained for the nepheline concentrate-slag-water binder (Figure 3, Table 3), the nepheline containing tailings-slag mixture was mechanically activated in $\mathrm{CO}_{2}$ atmosphere as described in Section 2.1. With an increase in the content of the nepheline containing 
tailings in the composition, the strength decreased. However, at $28 \mathrm{~d}$ of age, it was not less than 15 $\mathrm{MPa}$. The compressive strength of the binder based on the mechanically activated mixture of the nepheline containing tailings and the slag with a mass ratio of 1:1 at 7-360 $\mathrm{d}$ of age was in the range of 50-57 MPa. The corresponding value for the binder based on $(20 \%$ slag $+80 \%$ nepheline containing tailings) mixture was in the range of 30-39 $\mathrm{MPa}[3]$.

Table 8. The compressive strength (R) of the NT-Cu-Ni slag-liquid glass binder. MA was carried out in $\mathrm{CO}_{2}$ for $270 \mathrm{~s}$. Liquid glass contained $3.5 \mathrm{wt}$. \% $\mathrm{Na}_{2} \mathrm{O}$ relative to weight of $(\mathrm{NT}+\mathrm{Cu}-\mathrm{Ni}$ slag) mixture; silica modulus of liquid glass was 1.59. Curing was carried out under relative humidity of $95 \pm 5 \%$ at temperature of $20-22{ }^{\circ} \mathrm{C}$. Water to solid ratio was $0.23 ; \mathrm{S}_{\mathrm{sp}}$ : the specific surface area of the NT-Cu-Ni slag mixture.

\begin{tabular}{cccccccc}
\hline Composition, wt. $\%$ & \multirow{2}{*}{$\mathbf{S}_{\mathbf{s p}}, \mathbf{m}^{\mathbf{2}} \cdot \mathbf{k g}^{-\mathbf{1}}$} & \multicolumn{4}{c}{$\mathbf{R}, \mathbf{M P a}$} \\
\cline { 1 - 4 } Nepheline Containing Tailings & $\mathbf{C u}-\mathbf{N i}$ Slag & & & $\mathbf{7 ~ d}$ & $\mathbf{2 8} \mathbf{d}$ & $\mathbf{1 8 0} \mathbf{~ d}$ & $\mathbf{3 6 0 ~ d}$ \\
\hline 20 & 80 & 801 & 68.5 & 71.1 & 72.1 & 74.9 \\
30 & 70 & 714 & 58.4 & 68.2 & 68.9 & 71.4 \\
50 & 50 & 660 & 50.4 & 52.4 & 53.4 & 56.9 \\
80 & 20 & 1086 & 30.2 & 26.8 & 33.4 & 38.8 \\
100 & - & 1470 & 10.7 & 15.9 & 16.6 & - \\
\hline
\end{tabular}

\section{Blended Cements Prepared Using the Nepheline Concentrate and the Nepheline Containing Tailings Dumps}

In modern building materials science, one of the topical problems is development of blended cements based on Portland cement (PC) and various natural and technogenic raw materials. With the correct selection of the compositions and the method of pre-treatment of the raw mixtures, it is possible not only not to impair the physical-mechanical properties of Portland cement, but also to obtain materials with a higher level of the strength and other characteristics. Such an approach allows saving energy resources and improving the ecological situation without reducing the quality of the cement [54-58]. An additional positive effect from the point of view of increasing the strength of the cement stone can be achieved through the use of mechanical activation of the blended cement components [59-63]. This section presents the results of studies on the binding properties of blends based on Portland cement and the nepheline containing additives using mechanical activation. As nepheline-containing additives, the nepheline concentrate of Joint-stock company "Apatit" and tailings of Joint-stock company "Lovozersky GOK" (Murmansk Region, Russia) were used. Data on the binding properties of the mechanically activated gypsum-nepheline concentrate composition are also given.

\subsection{Blends Based on Portland Cement and the Nepheline Containing Additives}

The binding properties of the Portland cement-nepheline concentrate blend in which the nepheline concentrate content varied from 1 to $80 \mathrm{wt}$. \% were studied in [64]. To prepare the blends, Portland cement clinker of the Savinsky cement plant with addition of 5\% natural gypsum (Arkhangelsk region, Russia) were used. Mechanical activation of the Portland cement-nepheline concentrate blend was carried out in air for $150 \mathrm{~s}$ as described in Section 2.1. The specimens, cubes with plastic consistency, were prepared using the mechanically activated Portland cement-nepheline concentrate blend and cured under relative humidity of $95 \pm 5 \%$ at temperature of $20-22{ }^{\circ} \mathrm{C}$.

Figure 5 depicts the relative compressive strength $\left(\mathrm{R}_{\mathrm{rel}}\right)$ of the mechanically activated Portland cement-nepheline concentrate blend depending on percentage mass of the nepheline concentrate in the blend. The $R_{\text {rel }}$ was defined as $\left(R_{\text {blend }} / R_{P C}\right) \cdot 100 \%$, where $R_{\text {blend }}$ and $R_{P C}$ were the compressive strength of the blend and $100 \%$ Portland cement mechanically activated under the same conditions and cured for the same time, respectively. It was revealed that addition of the nepheline concentrate to Portland cement in amounts of 1 to $30 \mathrm{wt}$. \% increased the compressive strength up to the $R_{\text {rel }}$ of $130 \%$ 
and $115 \%$ at $28 \mathrm{~d}$ and $360 \mathrm{~d}$ ages, respectively (Figure 5). As a result of mechanical activation of the blend, defects were formed on the surface of nepheline particles, which, apparently, were active centers that accelerated the hydration of clinker minerals by the mechanism of heterogeneous nucleation [64].

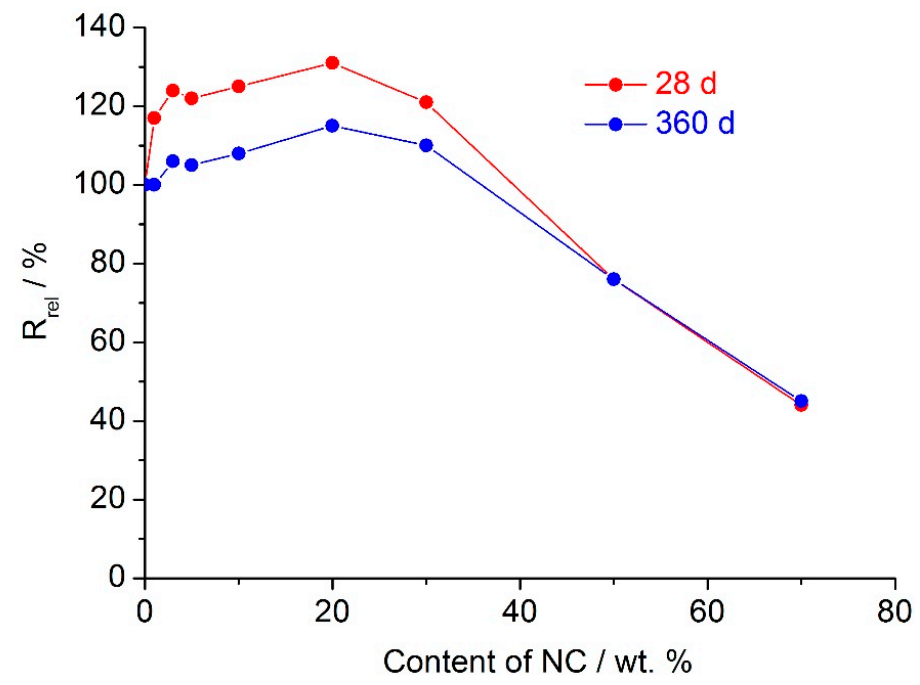

Figure 5. Variation of the relative compressive strength $\left(\mathrm{R}_{\mathrm{rel}}\right)$ of the mechanically activated Portland cement-nepheline concentrate blend at 28 and $360 \mathrm{~d}$ of age as a function of percentage mass of the nepheline concentrate in the blend.

The supporting evidence for this hypothesis was obtained from investigation of the dynamics of phase formation in the early stages of hardening of the mechanically activated Portland cement-nepheline concentrate blend using in situ X-ray diffraction in conjunction with the Rietveld method [65]. The content of Portland cement in the blend was $30 \mathrm{wt}$. \%. Mechanical activation of the Portland cement without additive and the Portland cement-nepheline concentrate blend was carried out in air for $270 \mathrm{~s}$. The percentages of $\mathrm{Ca}_{3} \mathrm{SiO}_{5}$ (alite) and $\mathrm{Ca}(\mathrm{OH})_{2}$ (portlandite) in a hardening paste as functions of curing time for $100 \%$ Portland cement and the Portland cement-nepheline concentrate blend are presented in Figures 6 and 7, respectively. For comparison purposes, for the Portland cement, nepheline concentrate blends the calculated content of alite (Figure 6, curve 2) and portlandite (Figure 7, curve 2) were normalized to " $100 \%$ Portland cement", that is, the content of the nepheline concentrate in the blend was not taken into consideration [65].

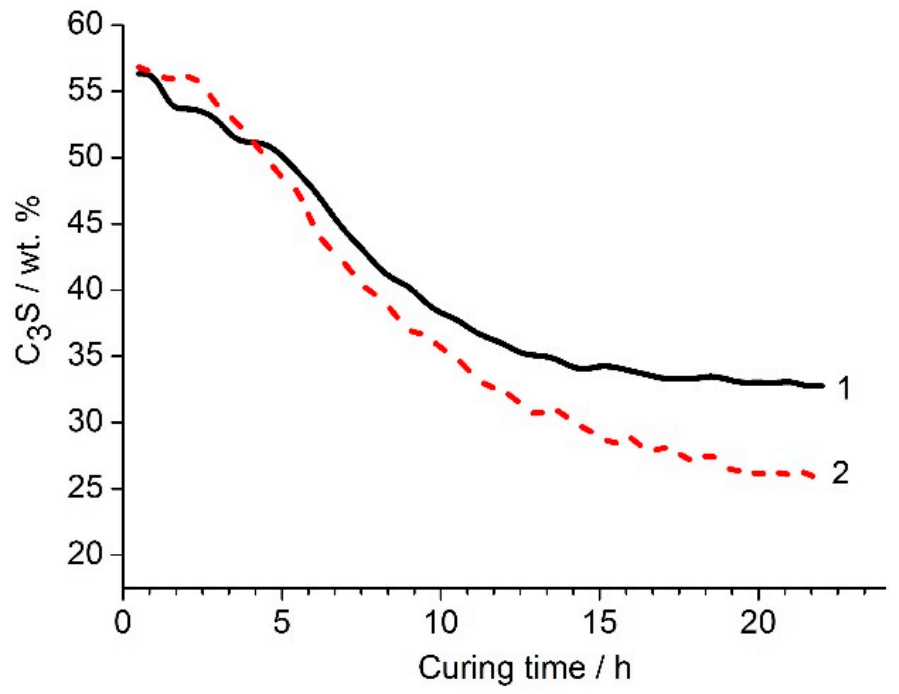

Figure 6. Variation of the alite $\left(\mathrm{C}_{3} \mathrm{~S}\right)$ content in the paste as a function of curing time: PC (1) and PC-NC blend (2). 


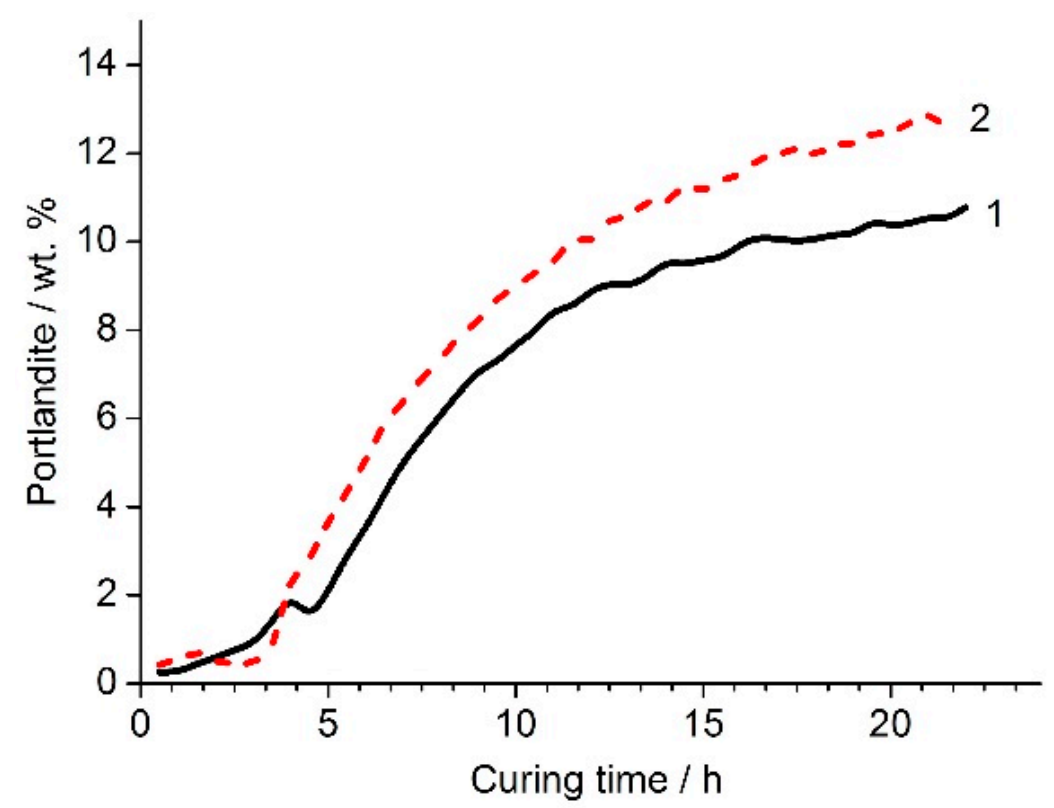

Figure 7. Variation of the portlandite content in the paste as a function of curing time: PC (1) and PC-NC blend (2).

In accordance with the hydration reaction of $\mathrm{Ca}_{3} \mathrm{SiO}_{5}[66]$.

$\mathrm{Ca}_{3} \mathrm{SiO}_{5}$ (alite) $+3.9 \mathrm{H}_{2} \mathrm{O} \rightarrow(\mathrm{CaO})_{1.7} \cdot \mathrm{SiO}_{2} \cdot 2.6 \mathrm{H}_{2} \mathrm{O}\left(\mathrm{C}-\mathrm{S}-\mathrm{H}\right.$ gel) $+1.3 \mathrm{Ca}(\mathrm{OH})_{2}$ (portlandite)

The decrease in the alite content (Figure 6) occurred consistently with of the increase in the content of portlandite (Figure 7). For the Portland cement-nepheline concentrated blend, by the end of the first day of hardening, the degree of the alite hydration was notably higher than that for $100 \%$ Portland cement. The nepheline containing mining wastes can be used as a stowing material for spent underground mine workings. The authors of [67] developed composite binder based on the jointly ball milled Portland cement and the nepheline containing flotation tailings of the Joint-stock company "Lovozersky GOK". These tailings consisted of 55-65\% nepheline, and also contained feldspar and aegirine. It was shown that the Portland cement-tailings blend milled to a specific surface area of $2500-4000 \mathrm{~cm}^{2} \cdot \mathrm{g}^{-1}$ exhibited compressive strength of $30 \mathrm{MPa}$ at $28 \mathrm{~d}$ age. The content of Portland cement in such blends was about $50 \%$, and for stowing operations it could be reduced to $10-20 \%$.

\subsection{Gypsum-Nepheline Concentrate Blend}

The binding properties of the mechanically activated natural gypsum-nepheline concentrate blend was studied in [68]. The content of the natural gypsum in the blend ranged from 5 to $70 \mathrm{wt}$. \%. Mechanical activation of the blend was carried out in air for $270 \mathrm{~s}$ as described in Section 2.1. The use of $\mathrm{CaSO}_{4} \cdot 2 \mathrm{H}_{2} \mathrm{O}$ in composite binders allows for excluding the calcination operation in comparison with the known gypsum technology.

During joint mechanical activation of the blend, along with decreasing of particle size of the gypsum and nepheline according to the data of X-ray diffraction analysis the intensities of the peaks decreased and their broadening occurred (Figure 8). Moreover, for softer gypsum (hardness on the Mohs scale, 2), this process was more pronounced than for nepheline (hardness, 5.5-6.0). In addition, according to thermal analysis data (not shown) mechanical activation of the blend resulted in partial dehydration of gypsum. After $270 \mathrm{~s}$ of mechanical activation, the content of crystallization water was $40-45 \mathrm{wt}$. \% of its content in the initial gypsum. These factors increased the solubility of gypsum and contributed to its further recrystallization. Recrystallization of $\mathrm{CaSO}_{4} \cdot 2 \mathrm{H}_{2} \mathrm{O}$ was evidenced by an increase in intensities and a decrease in the width of its reflections in the X-ray diffraction pattern of the cured sample (Figure 8, curve 3), as compared to $\mathrm{CaSO}_{4} \cdot 2 \mathrm{H}_{2} \mathrm{O}$ reflections in a mechanically activated mixture (Figure 8, curve 2). 


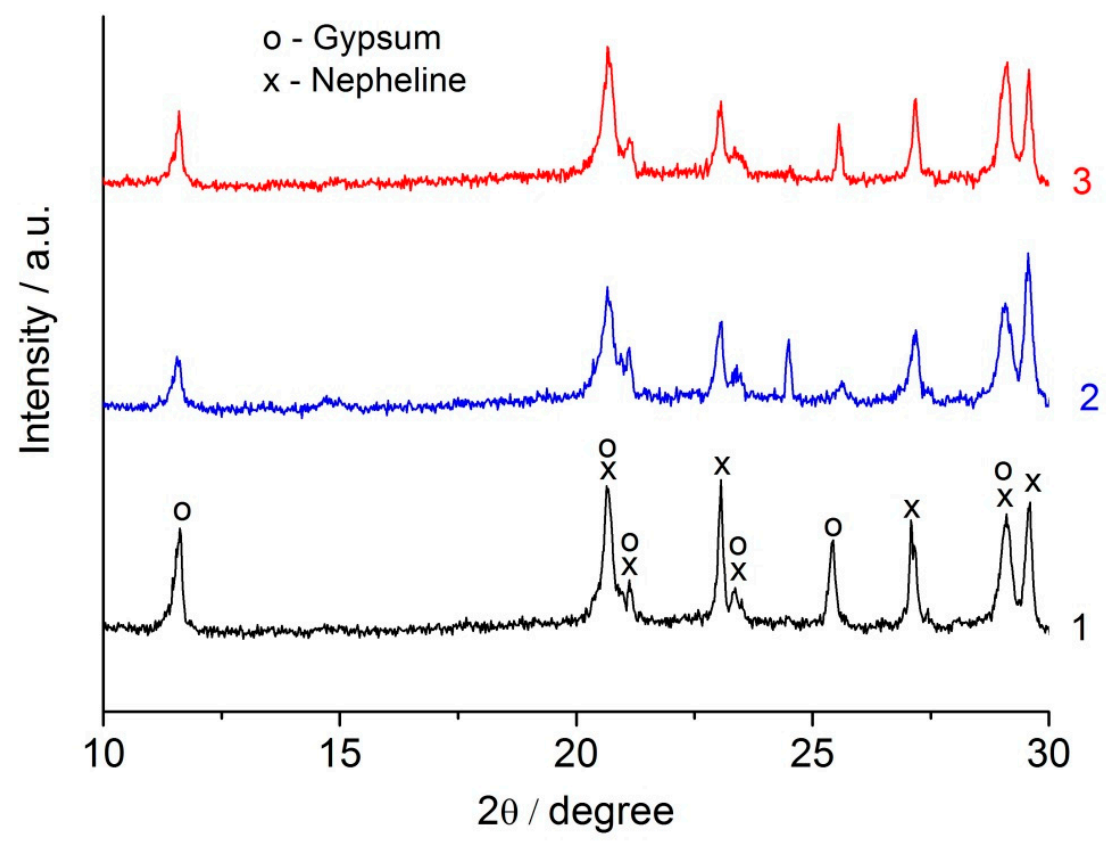

Figure 8. X-ray diffraction patterns: the initial (50\% NC + 50\% gypsum) mixture (1); the mechanically activated for $270 \mathrm{~s}(50 \% \mathrm{NC}+50 \%$ gypsum) mixture (2); 1 day-old paste prepared using the mechanically activated for $270 \mathrm{~s}(50 \% \mathrm{NC}+50 \%$ gypsum) mixture cured at relative humidity of $60-70 \%$ (3). The main crystalline peaks are labeled.

Using the Scherrer's formula, the average crystallite size of $\mathrm{CaSO}_{4} \cdot 2 \mathrm{H}_{2} \mathrm{O}$ depending on the curing time in air for the mechanically activated (50\% nepheline concentrate $+50 \%$ gypsum) blend was calculated (Figure 9). During the first $7 \mathrm{~d}$ of curing, the size of gypsum crystallites as a result of recrystallization increased 1.7 times in comparison to that of the initial gypsum and subsequently remained virtually unchanged. This was consistent with the compressive strength of the corresponding binders (Figure 10).

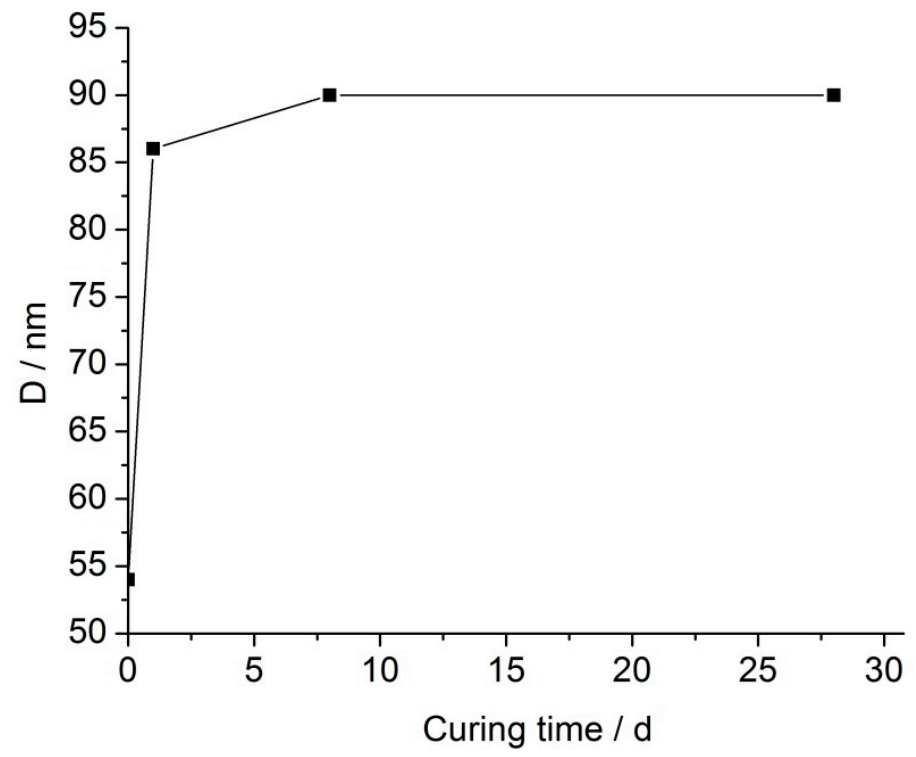

Figure 9. Variation of the $\mathrm{CaSO}_{4} \cdot 2 \mathrm{H}_{2} \mathrm{O}$ crystallite size in terms of curing time for the binder prepared using the (50\% NC $+50 \%$ gypsum) mixture milled for $270 \mathrm{~s}$ and cured at relative humidity of $60-70 \%$ at $20-22{ }^{\circ} \mathrm{C}$. 


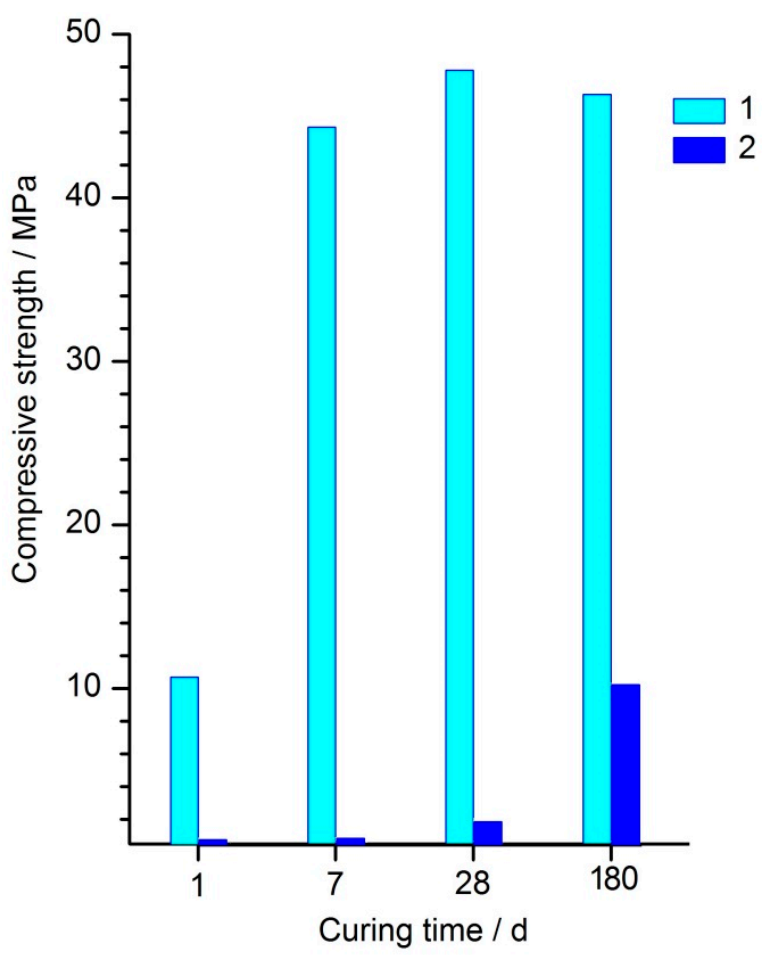

Figure 10. Variation of the compressive strength in terms of curing time for the binder prepared using the $\left(50 \%\right.$ nepheline concentrate $+50 \%$ gypsum) mixture milled for $270 \mathrm{~s}$ and cured at $20-22{ }^{\circ} \mathrm{C}$. Curing conditions: 1 -a relative humidity of $60-70 \%, 2$ - a relative humidity of $95-100 \%$.

The gypsum-nepheline concentrate blend according to the results obtained was an "airy" binder. The compressive strength of the binder based on the mechanically activated mixtures of gypsum and the nepheline concentrate with a mass ratio of $1: 1$, cured in air at a relative humidity of $60-70 \%$ reached $\sim 10 \mathrm{MPa}$ after $1 \mathrm{~d}$ of curing, and increased to $48 \mathrm{MPa}$ after $28 \mathrm{~d}$ of curing (Figure 10). The strength of building gypsum usually does not exceed $25 \mathrm{MPa}$ (grade G25 according to GOST-Russian National Standard).

When curing at a relative humidity of $95-100 \%$, the compressive strength was low, but, in six months, it reached $10 \mathrm{MPa}$. It should be noted that an indirect additional confirmation of the influence of the nepheline concentrate on the recrystallization and hardening of gypsum in the mechanically activated gypsum-nepheline concentrate blend was the noticeable strength of the binders upon curing at a relative humidity of $95-100 \%$ (Figure 10 ).

\section{Conclusions}

In summary, the nepheline-containing mining waste accumulated in gigantic amounts on the territory of the Kola Peninsula has great potential for producing a variety of effective and resource saving binders. It was proved that nepheline was an active additive in the binders. Nepheline affected the processes of formation of cement stone, while not only not worsening, but also increasing physical and mechanical characteristics of the binders. The results presented in this review are the basis for further research aimed at obtaining building materials using nepheline, which will find application not only as a stowing material for spent underground mine workings, but also in civil engineering.

Author Contributions: Conceptualization, B.I.G., E.V.K., and A.M.K.; Writing-Original Draft Preparation. B.I.G., E.V.K., and A.M.K.; Writing-Review and Editing, B.I.G., E.V.K., and A.M.K.; Visualization, E.V.K. and A.M.K. All authors have read and agreed to the published version of the manuscript.

Funding: The research was supported by the Federal Research Centre "Kola Science Centre of the Russian Academy of Sciences" (Contract No. 0226-2019-0068).

Conflicts of Interest: The authors declare no conflict of interest. 


\section{References}

1. Arkhipov, A.V.; Reshetnyak, S.P. Technogenic Deposits. Development and Formation; Kola Science Center of RAS: Apatity, Russia, 2017; p. 175. (In Russian)

2. Masloboev, V.A.; Makarov, D.V.; Baklanov, A.A.; Amosov, P.V.; Seleznev, S.G. Methods to Reduce the Environmental Hazards of Mining and Processing of Minerals in the Arctic Regions. In Proceedings of the International Mineral Processing Congress 2016 XXVIII, Quebec City, QC, Canada, 11-15 September 2016; Available online: https://www.researchgate.net/publication/316433230 (accessed on 20 November 2019).

3. Kalinkin, A.M.; Gurevich, B.I.; Kalinkina, E.V.; Tyukavkina, V.V.; Mazukhina, S.I. Geopolymer materials using mechanically activated nepheline and nepheline-containing waste. Izv. SPbGTI (TU) 2016, 37, 95-99. (In Russian)

4. Matveev, V.A.; Mayorov, D.V.; Velyaev, Y.O.; Zakharov, V.I. Sulfuric Acid Methods of Complex Processing of Nepheline-Containing Raw Materials; Kola Science Center of RAS: Apatity, Russia, 2017; p. 155. (In Russian)

5. Tait, K.T.; Sokolova, E.; Hawthorne, F.C.; Khomyakov, A.P. The crystal chemistry of nepheline. Can. Mineral. 2003, 41, 61-70. [CrossRef]

6. Glukhovsky, V.D.; Krivenko, P.V.; Starchuk, V.N.; Pashkov, I.A.; Chirkova, V.V. Alkali Activated Slag Concrete Using Fine-Grain Aggregate; Vischa Shkola: Kiev, Ukraine, 1981. (In Russian)

7. Von Heinicke, G. Tribochemistry; Akademie: Berlin, Germany, 1984; p. 495. [CrossRef]

8. Avvakumov, E.G.; Gusev, A.A. Mechanical Activation Methods in the Processing of Natural and Technogenic Raw Materials; Geo: Novosibirsk, Russia, 2009; p. 155. (In Russian)

9. Boldyrev, V.V. Mechanochemistry and Mechanical Activation of Solids. Russ. Chem. Rev. 2006, 75, 177-189. [CrossRef]

10. Baláž, P. Mechanochemistry in Nanoscience and Minerals Engineering; Springer: Berlin/Heidelberg, Germany, 2008; p. 413.

11. Provis, J.L.; Palomo, A.; Shi, C. Advances in understanding alkali-activated materials. Cem. Concr. Res. 2015, 78A, 110-125. [CrossRef]

12. Provis, J.L. Alkali-activated Materials. Cem. Concr. Res. 2018, 114, 40-48. [CrossRef]

13. Davidovits, J. Geopolymers: Ceramic-like Inorganic Polymers. J. Ceram. Sci. Technol. 2017, 8, 335-349. [CrossRef]

14. Provis, J.L.; van Deventer, J.S.J. (Eds.) Alkali-Activated Materials: State of the Art Report of RILEM TC 224-AAM; Springer Science \& Business Media: Dordrecht, The Netherlands, 2014; p. 388. [CrossRef]

15. Provis, J.L.; Bernal, S.A. Geopolymers and related alkali-activated materials. Annu. Rev. Mater. Res. 2014, 44, 299-327. [CrossRef]

16. Krivenko, P. Why alkaline activation-60 years of the theory and practice of alkali-activated materials. J. Ceram. Sci. Technol. 2017, 8, 323-333. [CrossRef]

17. Part, W.K.; Ramli, M.; Cheah, C.B. An overview on the influence of various factors on the properties of geopolymer concrete derived from industrial by-products. Constr. Build. Mater. 2015, 77, 370-395. [CrossRef]

18. Van Deventer, J.S.J.; Provis, J.L.; Duxson, P.; Lukey, G.C. Reaction mechanisms in the geopolymeric conversion of inorganic waste to useful products. J. Hazard. Mater. 2007, 139, 506-513. [CrossRef]

19. Mehta, A.; Siddique, R. An overview of geopolymers derived from industrial by-products. Constr. Build. Mater. 2016, 127, 183-198. [CrossRef]

20. Kastiukas, G.; Zhou, X. Effects of waste glass on alkali-activated tungsten mining waste: Composition and mechanical properties. Mater. Struct. 2017, 50, 194. [CrossRef]

21. Kastiukas, G.; Zhou, X.; Castro-Gomes, J. Preparation Conditions for the Synthesis of Alkali-Activated Binders Using Tungsten Mining Waste. J. Mater. Civ. Eng. 2017, 29, 04017181. [CrossRef]

22. Falah, M.; Obenaus-Emler, R.; Kinnunen, P.; Illikainen, M. Effects of activator properties and curing conditions on alkali-activation of low-alumina mine tailings. Waste Biomass Valoriz. 2019. [CrossRef]

23. Manjarrez, L.; Nikvar-Hassani, A.; Shadnia, R.; Zhang, L. Experimental study of geopolymer binder synthesized with copper mine tailings and low-calcium copper slag. J. Mater. Civ. Eng. 2019, 31, 04019156. [CrossRef] 
24. Pacheco-Torgal, F.; Castro-Gomes, J.P.; Jalali, S. Investigations of tungsten mine waste geopolymeric binder: Strength and microstructure. Constr. Build. Mater. 2008, 22, 2212-2219. [CrossRef]

25. Sedira, N.; Castro-Gomes, J. Effect of activators on hybrid alkaline binder based on tungsten mining waste and ground granulated blast furnace slag. Constr. Build. Mater. 2020, 232, 117176. [CrossRef]

26. Ahmari, S.; Zhang, L. Production of eco-friendly bricks from copper mine tailings through geopolymerization. Constr. Build. Mater. 2012, 29, 323-331. [CrossRef]

27. Bernal, S.A.; Rodríguez, D.; Kirchheim, A.P.; Provis, J.L. Management and valorisation of wastes through use in producing alkali-activated cement materials. J. Chem. Technol. Biotechnol. 2016, 91, 2365-2388. [CrossRef]

28. Venu Madhav, T.; Ramana Reddy, I.V.; Ghorpade, V.G.; Jyothirmai, S. Compressive strength study of geopolymer mortar using quarry rock dust. Mater. Lett. 2018, 231, 105-108. [CrossRef]

29. Capasso, I.; Lirer, S.; Flora, A.; Ferone, C.; Cioffi, R.; Caputo, D.; Liguori, B. Reuse of mining waste as aggregates in fly ash-based geopolymers. J. Clean. Prod. 2019, 220, 65-73. [CrossRef]

30. Moukannaa, S.; Nazari, A.; Bagheri, A.; Loutou, M.; Sanjayan, J.G.; Hakkou, R. Alkaline fused phosphate mine tailings for geopolymer mortar synthesis: Thermal stability, mechanical and microstructural properties. J. Non-Cryst. Solids 2019, 511, 76-85. [CrossRef]

31. Wang, A.; Liu, H.; Hao, X.; Wang, Y.; Liu, X.; Li, Z. Geopolymer Synthesis Using Garnet Tailings from Molybdenum Mines. Minerals 2019, 9, 48. [CrossRef]

32. Duan, P.; Yan, C.J.; Zhou, W.; Ren, D. Fresh properties, compressive strength and microstructure of fly ash geopolymer paste blended with iron ore tailing under thermal cycle. Constr. Build. Mater. 2016, 118, 76-88. [CrossRef]

33. Dabbebi, R.; de Aguiar, J.L.B.; Camões, A.; Samet, B.; Baklouti, S. Effect of the calcinations temperatures of phosphate washing waste on the structural and mechanical properties of geopolymeric mortar. Constr. Build. Mater. 2018, 185, 489-498. [CrossRef]

34. Wei, B.; Zhang, Y.; Bao, S. Preparation of geopolymers from vanadium tailings by mechanical activation. Constr. Build. Mater. 2017, 145, 236-242. [CrossRef]

35. Luukkonen, T.; Heponiemi, A.; Runtti, H.; Pesonen, J.; Yliniemi, J.; Lassi, U. Application of alkali-activated materials for water and waste water treatment: A review. Rev. Environ. Sci. Biotechnol. 2019, 18, 271-297. [CrossRef]

36. Ma, C.-K.; Awang, A.Z.; Omar, W. Structural and material performance of geopolymer concrete: A review. Constr. Build. Mater. 2018, 186, 90-102. [CrossRef]

37. Bai, C.; Colombo, P. Processing, properties and applications of highly porous geopolymers: A review. Ceram. Int. 2018, 44, 16103-16118. [CrossRef]

38. Tang, Z.; Li, W.; Hu, Y.; Zhou, J.L.; Tam, V.W.Y. Review on designs and properties of multifunctional alkali-activated materials (AAMs). Constr. Build. Mater. 2019, 200, 474-489. [CrossRef]

39. Ding, Y.; Dai, J.-G.; Shi, C.-J. Mechanical properties of alkali-activated concrete: A state-of-the-art review. Constr. Build. Mater. 2016, 127, 68-79. [CrossRef]

40. Fernandez-Jimenez, A.; Garcia-Lodeiro, I.; Maltseva, O.; Palomo, A. Mechanical-chemical activation of coal fly ashes: An effective way for recycling and make cementitious materials. Front. Mater. 2019, 6. [CrossRef]

41. Tchadjie, L.N.; Ekolu, S.O. Enhancing the reactivity of aluminosilicate materials toward geopolymer synthesis. J. Mater. Sci. 2018, 53, 4709-4733. [CrossRef]

42. Kumar, S.; Kumar, R. Mechanical activation of fly ash: Effect on reaction, structure and properties of resulting geopolymer. Ceram. Int. 2011, 37, 533-541. [CrossRef]

43. Djobo, J.N.Y.; Elimbi, A.; Tchakoute, H.K.; Kumar, S. Mechanical Activation of Volcanic Ash for Geopolymer Synthesis: Effect on Reaction Kinetics, Gel Characteristics, Physical and Mechanical Properties. RSC Adv. 2016, 6, 39106-39117. [CrossRef]

44. Mucsi, G. Mechanical Activation of Power Station Fly Ash by Grinding: A Review. J. Silic. Based Compos. Mater. 2016, 68, 56-61.

45. Marjanovic, N.; Komljenovic, M.; Bascarevic, Z.; Nikolic, V. Improving reactivity of fly ash and properties of ensuing geopolymers through mechanical activation. Constr. Build. Mater. 2014, 57, 151-162. [CrossRef] 
46. Temuujin, J.; Williams, R.P.A.; van Riessen, A. Effect of mechanical activation of fly ash on the properties of geopolymer cured at ambient temperature. J. Mater. Process. Technol. 2009, 209, 5276-5280. [CrossRef]

47. Gurevich, B.I.; Kalinkin, A.M.; Kalinkina, E.V.; Mazukhina, S.I.; Tyukavkina, V.V. Geopolymer binder based on mechanically activated compositions of magnesia-ferrous slag and nepheline. Perspekt. Mater. 2015, 3, 63-71. (In Russian)

48. Glukhovsky, V.D. Soil Silicates; Gosstroyizdat Ukrainskoy SSR: Kiev, Ukraine, 1959; p. 125. (In Russian)

49. Glukhovsky, V.D. Ancient, modern and future concretes. In Proceedings of the 1st International Conference on Alkaline Cements and Concretes; Krivenko, P.V., Ed.; VIPOL Stock Company: Kiev, Ukraine, 1994; pp. 1-9. (In Russian)

50. Gurevich, B.I.; Zosin, A.P. Binder based on nickel slag and liquid glass. In Metallurgical Slag of Moncha and Pechenga; Tenner, D.D., Ed.; Nauka: Moscow/Leningrad, Russia, 1965; pp. 147-167. (In Russian)

51. Gurevich, B.I. Binders Produced from Technogeneous Raw Materials of the Kola Peninsula; Kola Science Center of RAS: Apatity, Russia, 1996; p. 179. (In Russian)

52. Kalinkin, A.M.; Kumar, S.; Gurevich, B.I.; Alex, T.C.; Kalinkina, E.V.; Tyukavkina, V.V.; Kalinnikov, V.T.; Kumar, R. Geopolymerization behavior of $\mathrm{Cu}-\mathrm{Ni}$ slag mechanically activated in air and in $\mathrm{CO}_{2}$ atmosphere. Int. J. Miner. Process. 2012, 112, 101-106. [CrossRef]

53. Kalinkin, A.M.; Gurevich, B.I.; Myshenkov, M.S.; Kalinkina, E.V.; Zvereva, I.A. A calorimetric study of hydration of magnesia-ferriferous slag mechanochemically activated in air and in $\mathrm{CO}_{2}$ atmosphere. J. Therm. Anal. Calorim. 2018, 134, 165-171. [CrossRef]

54. Paris, J.M.; Roessler, J.G.; Ferraro, C.C.; DeFord, H.D.; Townsend, T.G. A review of waste products utilized as supplements to Portland cement in concrete. J. Clean. Prod. 2019, 121,1-18. [CrossRef]

55. Juenger, M.; Snellings, R.; Bernal, S.A. Supplementary cementitious materials: New sources, characterization, and performance insights. Cem. Concr. Res. 2019, 122, 257-273. [CrossRef]

56. Feng, Y.; Yang, Q.; Chen, Q.; Kero, J.; Andersson, A.; Ahmed, H.; Engström, F.; Samuelsson, C. Characterization and evaluation of the pozzolanic activity of granulated copper slag modified with CaO. J. Clean. Prod. 2019, 232, 1112-1120. [CrossRef]

57. Martínez-Martínez, S.; Pérez-Villarejo, L.; Eliche-Quesada, D.; Sánchez-Soto, P.J.; Christogerou, A.; Kanellopoulou, D.G.; Angelopoulos, G.N. New waste-based clinkers for the preparation of low-energy cements. A step forward toward circular economy. Int. J. Appl. Ceram. Technol. Spec. Issue Artic. 2019. [CrossRef]

58. Rocha, S.; Sousa-Coutinho, J. Construction and demolition waste as partial cement replacement. Adv. Cem. Res. 2019, 31, 411-422. [CrossRef]

59. Kumar, S.; Bandopadhyay, A.; Rajinikanth, V.; Alex, T.C.; Kumar, R. Improved processing of blended slag cement through mechanical activation. J. Mater. Sci. 2004, 39, 3449-3452. [CrossRef]

60. Singla, R.; Kumar, S.; Alex, T.C. Reactivity alteration of granulated blast furnace slag by mechanical activation for high volume usage in Portland slag cement. Waste Biomass Valoriz. 2019. [CrossRef]

61. Bouzoubaâ, N.; Zhang, M.H.; Bilodeau, A.; Malhotra, V.M. The effect of grinding on the physical properties of fly ashes and a portland cement clinker. Cem. Concr. Res. 1997, 27, 1861-1874. [CrossRef]

62. Kumar, S.; Kumar, R.; Bandopadhyay, A.; Alex, T.C.; Kumar, B.R.; Das, S.K.; Mehrotra, S.P. Mechanical activation of granulated blast furnace slag and its effect on the properties and structure of portland slag cement. Cem. Concr. Compos. 2008, 30, 679-685. [CrossRef]

63. Mucsi, G.; Rácz, Á.; Mádai, V. Mechanical activation of cement in stirred media mill. Powder Technol. 2013, 235, 163-172. [CrossRef]

64. Gurevich, B.I.; Kalinkin, A.M.; Kalinkina, E.V.; Tyukavkina, V.V. Effect of the mechanical activation of nepheline concentrate on Its binding properties in mixed cements. Russ. J. Appl. Chem. 2013, 86, 965-970. [CrossRef]

65. Kalinkin, A.M.; Krzhizhanovskaya, M.G.; Gurevich, B.I.; Kalinkina, E.V.; Tyukavkina, V.V. Hydration of mechanically activated blended cements studied by in situ X-Ray diffraction. Inorg. Mater. 2015, 51, 828-833. [CrossRef] 
66. Hesse, C.; Goetz-Neunhoeffer, F.; Neubauer, J.; Braeu, M.; Gaeberlein, P. Quantitative in-situ X-ray diffraction analysis of early hydration of Portland cement at defined temperatures. Powder Diffr. 2009, 24, 112-115. [CrossRef]

67. Bessonov, I.I.; Leont'ev, A.A.; Konokhov, V.P.; Gumennikov, V.P.; Gurevich, B.I. Zakladochnye Materialy iz Otkhodov Proizvodstva (Stowing Materials Produced from Industrial Wastes); Kol'skii Filial Akad. Nauk SSSR: Apatity, Russia, 1988; p. 72. (In Russian)

68. Gurevich, B.I.; Kalinkin, A.M.; Kalinkina, E.V.; Tyukavkina, V.V. Composite mechanically activated binder based on two-water gypsum. Proc. Kola Sci. Cent. RAS 2018, 1 Pt 2, 828-832. (In Russian)

(C) 2020 by the authors. Licensee MDPI, Basel, Switzerland. This article is an open access article distributed under the terms and conditions of the Creative Commons Attribution (CC BY) license (http://creativecommons.org/licenses/by/4.0/). 